\title{
Efficacy of cinnamon bark oil and cinnamaldehyde on anti-multidrug resistant Pseudomonas aeruginosa and the synergistic effects in combination with other antimicrobial agents
}

\author{
Itsaraporn Utchariyakiat', Suvimol Surassmo², Montree Jaturanpinyo ${ }^{3}$, Piyatip Khuntayaporn ${ }^{1}$
} and Mullika Traidej Chomnawang ${ }^{\text {* }^{*}}$

\begin{abstract}
Background: The emergence of drug resistant pathogens becomes a crucial problem for infectious diseases worldwide. Among these bacteria, Pseudomonas aeruginosa is one of which highly resists to many currently used drugs and becomes a major concern in public health. Up till now, the search for potential antimicrobial agents has been still a challenge for researchers.

Methods: Broth microdilution assay was used to determine minimum inhibitory concentrations (MICs) and minimum bactericidal concentrations (MBCs) of the essential oils and antibiotics against $P$. aeruginosa. Inhibition activity of the essential oils under vapor condition was examined to obtain the minimum inhibitory dose (MID). Time-kill assay included in this study was performed according to CLSI guideline. Bioautographic assay was used to detect active components of the essential oil. Synergistic effect with currently used antibiotics was further examined by checkerboard assay.

Results and Discussion: In this study, a variety of essential oils were examined for anti-multidrug resistant $P$. aeruginosa (MDR-PA) activity, of which cinnamon bark oil showed the strongest antimicrobial activity against all clinical-isolated MDR-PA strains with MIC of $0.0562-0.225 \% \mathrm{v} / \mathrm{V}$ and MBC of $0.1125-1.8 \% \mathrm{v} / \mathrm{v}$.

Bioautographic results demonstrated that the active compounds of cinnamon bark oil were cinnamaldehyde and eugenol which showed strong inhibitory effect against $P$. aeruginosa. Interestingly, cinnamaldehyde, a major constituent of cinnamon bark oil, possessed stronger antimicrobial effect to $P$. aeruginosa than eugenol. Under gaseous condition, cinnamon bark oil and cinnamaldehyde showed antibacterial activity against MDR-PA strains with MID of 0. 5-1 mg/L. Moreover, combination of cinnamon bark oil or cinnamaldehyde with currently used antibiotics was further studied by checkerboard assay to examine synergistic interactions on clinically isolated MDR-PA strains. Cinnamon bark oil and cinnamaldehyde combined with colistin demonstrated synergistic rates at 16.7 and $10 \%$, respectively.

Conclusion: These results indicated that cinnamon bark oil and cinnamaldehyde might be active natural compounds which could be further examined as alternative treatment for multidrug-resistant $P$. aeruginosa infection.
\end{abstract}

Keywords: Cinnamaldehyde, Cinnamon bark oil, Multidrug-resistant P. aeruginosa, Synergy

\footnotetext{
* Correspondence: mullika.tra@mahidol.ac.th

'Department of Microbiology, Faculty of Pharmacy, Mahidol University, 447

Sri Ayudthaya Road, Rachathevi, Bangkok 10400, Thailand

Full list of author information is available at the end of the article
} 


\section{Background}

Pseudomonas aeruginosa is a Gram-negative nonfermenting bacterium which has broad ecological adaptability and distribution. It is an opportunistic human pathogen, causing severe infections, especially in immunocompromised patients. This organism is classified as one of 'hard to treat' organisms and is one of the most antibiotic resistant bacteria in this century because of its adaptability to various conditions and multifactorial virulences; for example, endotoxin, exotoxin and proteolytic enzymes. In addition, $P$. aeruginosa has high intrinsic resistance to antibiotic and is able to develop new antibiotic resistance during treatment [1]. The ability of antibiotic resistance of $P$. aeruginosa is significantly due to low permeability of the cell wall, which restricts the uptake of antibiotics, and the genetic capacity to express a wide repertoire of resistance mechanisms, like efflux pumps and enzymes, which modify or degrade antibiotics and drug targets [2]. It was reported that the antibiotic tolerance of $P$. aeruginosa clinical isolates could enhance up to 6000fold to ciprofloxacin and tobramycin [3-5].

Plant essential oils are potential sources of antimicrobial compounds and have been used in traditional medicine for many years [6-9]. Essential oils are natural compounds containing a complex mixture of odorous and volatile constituents. Essential oils have been observed to possess antibacterial, antifungal and anti-plasmodial activity. Several in vitro studies indicated that essential oils exhibited antibacterial agents against wide spectrum of pathogenic bacterial strains [10, 11]. For example, the leaves and flowers of Achillea clavennae in Croatia were investigated by disc diffusion method against Gram-positive and Gram-negative bacteria and showed strong activity against Haemophilus influenzae and P. aeruginosa. Also in India, Aristolochia indica containing $\beta$ carophyllene and $\alpha$-humulene as major components was evaluated its antibacterial activity against six strains of bacteria by agar dilution method and demonstrated moderate activity [12]. Some essential oils such as oregano oil showed effects on multidrugresistant Escherichia coli [13]. Antibacterial activities of the essential oils from Ocimum gratissimum, Salvia officinalis L, Cymbopogon citratus (DC) stapf were evaluated on the microorganisms isolated from urinary tract infection and all of these microorganisms except $P$. aeruginosa showed sensitivity to these essential oils [14]. Therefore, this study was aimed to determine the effect of essential oils and its major compounds against multidrug-resistant $P$. aeruginosa. In addition, the combination of essential oils and its major compounds with currently used antibiotics were also investigated.

\section{Methods}

Bacterial strains, essential oils and antimicrobial agents Pseudomonas aeruginosa PAO1 and clinically isolated multidrug-resistant $P$. aeruginosa (MDR-PA) strains were cultured in tryptic soy broth (TSB) at $37{ }^{\circ} \mathrm{C}$ for $18 \mathrm{~h}$. The overnight culture was adjusted to an optical density of $0.5 \mathrm{McF}$ arland and was diluted to yield approximately $1.0 \times 10^{6} \mathrm{cfu} / \mathrm{ml}$.

Essential oils used in this study were betel vine oil (Piper betle Linn.), cinnamon bark oil (Cinnamomum zeylanicum), citronella oil (Cymbopogon nardus), clove oil, clove leaf oil (Syzygium aromaticum Linn. (Merr. \& Perry)), galangal oil (Alpinia galangal Linn.), guava leaf oil (Psidium guajava Linn.), hairy basil oil (Ocimum americanum Linn.), holy basil oil (Ocimum sanctum Linn.), kaffir lime oil, kaffir lime leaf oil (Citrus hystrix DC.), lemon oil (Citrus limonum Linn.), lemongrass oil (Cymbopogon flexuosus), finger root oil (Boesenbergia pandurata (Roxb.) Schltr), plai oil (Zingiber cassumunar Linn.), sweet basil oil (Ocimum bacilicum Linn.), and turmeric oil (Curcuma longa Linn.) which were purchased from Thai-China Flavours and Fragrances Industry Co., Ltd, Thailand. Cinnamaldehyde was obtained from S.M. chemical supplies Co., Ltd, Thailand. The essential oils and cinnamaldehyde were kept in light protection container at $4{ }^{\circ} \mathrm{C}$ to prevent oxidative degradation. Tween 80 and $95 \%$ ethanol were used as surfactant and cosurfactant to prepare essential oil solution. Essential oils and cinnamaldehyde were dissolved to appropriate concentration and stored at $4{ }^{\circ} \mathrm{C}$ before testing. Colistin sulfate was obtained from Acme Medical Co., Ltd, Thailand. Ceftazidime was purchased from Siam Bheasach Co., Ltd, Thailand. Imipenem and meropenem were purchased from L.B.S. Laboratory, Thailand. Piperacillin, and ciprofloxacin were purchased from Shionogi \& Co, Japan.

\section{Antimicrobial susceptibility test}

Determination of minimum inhibitory concentrations (MICs) and minimal bactericidal concentrations (MBCs) of the essential oils and antibiotics against $P$. aeruginosa PAO1 and clinical-isolated MDR-PA strains were performed by broth microdilution method as previously described [15]. MICs were obtained from the lowest concentration of active compound that inhibited bacterial growth. MBCs were further determined on MuellerHinton agar (MHA) and observed bacterial growth after 18-24 h incubation.

Inhibition activities under vapor condition of cinnamon bark oil, lemongrass oil, clove oil and cinnamaldehyde were examined on $P$. aeruginosa PAO1 and 19 MDR-PA isolates. The minimum inhibitory dose (MID) was defined as the lowest dose per unit space against bacterial growth. MID was expressed in term of weight per unit volume (mg/L air). Gaseous phase of essential 
oils were investigated on $P$. aeruginosa isolates according to Rodrigues FF et al. [16]. Briefly, essential oils were dissolved in dimethyl sulfoxide (DMSO) with ratio of 1:1 $\mathrm{w} / \mathrm{w}$, and dropped on paper disc. Agar plates were spread with bacterial suspension containing approximately $1.5 \times 10^{5} \mathrm{cfu} / \mathrm{ml}$ before placing paper disc on the lid of the petri dish and incubated at $37{ }^{\circ} \mathrm{C}$ for $24 \mathrm{~h}$ under closed system.

\section{Time killing assay}

Cinnamon bark oil and cinnamaldehyde were evaluated in terms of time killing effect on P. aeruginosa PAO1 and representative MDR-PA strain. Time-kill assay was performed according to CLSI guideline [17]. The concentrations of fosfomycin and carbapenems used in this assay to determine individual antimicrobial activity were selected from the Clinical Microbiology Procedures Handbook protocol [18]. Bacteria were inoculated in broth medium containing various concentrations of active compound as followed, 1xMIC, 2xMIC and 4xMIC. Treated bacterial cells were evaluated at a certain period of time by determining the cell viability and the bacterial growth compared to control.

\section{Thin Layer Chromatography and bioautography}

Active components of essential oil were identified by thin-layer chromatography (TLC). Silica gel GF254 plates (Merck KGaA, Darmstadt, Germany) were developed in system of toluene: ethyl acetate at a ratio of $93: 7 \mathrm{v} / \mathrm{v}$ according to Shahverdi et al. [19]. TLC paper coated with siliga gel was used as a stationary phase. They were developed in solvent system acting as mobile phase. The TLC plate was sprayed with $1 \% \mathrm{v} / \mathrm{v}$ anisaldehyde sulfuric acid and heated at $110{ }^{\circ} \mathrm{C}$ for 5 min before visualized under visible and UV lights (254 and $366 \mathrm{~nm}$ ). The constituents of compound were separated and calculated $\mathrm{R}_{f}$ values. TLC plates were performed in duplicate; one set was used as the reference chromatogram and another was used for bioautography. Bioautographic assay was performed to detect active components in essential oil [20]. Developed TLC plates were carefully dried to remove solvents, overlaid by agar seed, and incubated overnight at $37^{\circ} \mathrm{C}$. Inhibition zones were compared with $\mathrm{R}_{f}$ of the spots on the reference TLC plate.

\section{Synergistic activity}

The interaction between essential oils and the antibiotics, which were ceftazidime (CAZ), piperacilin (PIP), colistin sulfate (COL), meropenem (MEM), doripenem (DOR), imipenem (IMI) and ciprofloxacin (CIP), were determined by combination assay against MDR-PA isolates. Bacteria were cultured in broth medium for $18 \mathrm{~h}$ before adjusted to $0.5 \mathrm{McF}$ arland and the medium was diluted to obtain the concentration of $1.5 \times 10^{6} \mathrm{cfu} / \mathrm{ml}$.
Combination assay were examined in 96-well plate, the first agent was diluted by two-fold dilution, followed by adding the second agent at various concentrations. Then, bacterial suspension was added for into each well and incubated at $37^{\circ} \mathrm{C}$ for $24 \mathrm{~h}$. The fractional inhibitory concentration index (FICI) was calculated for each couple of drug combination. FICI was a summation between MIC of drug A in combination divided by MIC of drug $A$ alone $\left(C_{A}\right)$ and MIC of drug $B$ in combination divided by MIC of drug $B$ alone $\left(C_{B}\right)$.

$$
\begin{aligned}
\sum \mathrm{FICI} & =\mathrm{FIC}_{\mathrm{A}}+\mathrm{FIC}_{\mathrm{B}} \\
& =\left(\mathrm{C}_{\mathrm{A}} / \mathrm{MIC}_{\mathrm{A}}\right)+\left(\mathrm{C}_{\mathrm{B}} / \mathrm{MIC}_{\mathrm{B}}\right)
\end{aligned}
$$

Interpretation criteria of FICI were followed, if $\mathrm{FICI} \leq$ 0.5 indicate synergy, FICI between $>0.5$ and $\leq 4$ indicate indifferent, and FICI $>4$ mean antagonism [21].

\section{Results and Discussion}

Antimicrobial activity of essential oils against multidrug resistant $P$. aeruginosa

Antibacterial activity was performed on 17 essential oils against $P$. aeruginosa $\mathrm{PAO}$.

Three plant oils which were clove oil, lemongrass oil, and cinnamon bark oil showed effective antimicrobial activity. Among those, cinnamon bark oil gave the strongest inhibition activity against $P$. aeruginosa wildtype strain with MIC $0.2 \% \mathrm{v} / \mathrm{v}$ followed by clove oil and lemongrass oil with MICs of $1.8 \%$ v/v. Other 14 essential oils exhibited low antimicrobial efficacy against $P$. aeruginosa with $\mathrm{MIC}$ and $\mathrm{MBC}$ ranges of more than $1.8-3.6 \% \mathrm{v} / \mathrm{v}$. Moreover, cinnamon bark oil was only essential oil which demonstrated the strongest activity with $\mathrm{MBC}$ at the lowest used concentration $(0.2 \% \mathrm{v} / \mathrm{v})$. In addition, cinnamon bark oil, lemongrass oil and clove oil were further examined on 20 strains of clinical-isolated MDR-PA strains. Cinnamon bark oil showed the strongest activity against all MDR-PA isolates with MIC at 0.0562 $0.225 \% \mathrm{v} / \mathrm{v}$ and $\mathrm{MBC}$ at $0.1125-0.225 \% \mathrm{v} / \mathrm{v}$. Lemongrass oil ranked in the second with MIC at $0.45-1.8 \% \mathrm{v} / \mathrm{v}$ and $\mathrm{MBC}$ varied from 0.9 up to higher than $1.8 \% \mathrm{v} / \mathrm{v}$, while clove oil showed MIC varied from 0.9 up to higher than $1.8 \% \mathrm{v} / \mathrm{v}$ and $\mathrm{MBC}$ was more than $1.8 \% \mathrm{v} / \mathrm{v}$ (Table 1 ).

This study indicated that cinnamon bark oil demonstrated the most inhibitory effectiveness against clinicalisolated MDR-PA strains with MIC in range of 0.1125 to $0.225 \% \mathrm{v} / \mathrm{v}$ which was consistent with the previous study that cinnamon oil was the strongest antimicrobial agent. The researchers demonstrated that clove and cinnamon oil possessed potent inhibitory effect on various bacterial pathogens. Moreover, cinnamon oil showed promising antimicrobial activity which could inhibit all tested bacterial strains both Gram-negative and Grampositive bacteria with the lowest concentration among 
Table 1 Susceptibility tests of cinnamon bark oil, lemongrass oil and clove oil against clinical-isolated MDR-PA strains

\begin{tabular}{|c|c|c|c|c|c|c|}
\hline \multirow{3}{*}{$\begin{array}{l}\text { Isolated } \\
\text { strain }\end{array}$} & \multicolumn{2}{|c|}{ Cinnamon bark oil } & \multicolumn{2}{|c|}{ Clove oil } & \multicolumn{2}{|c|}{ Lemongrass oil } \\
\hline & MIC & $\mathrm{MBC}$ & $\mathrm{MIC}$ & $\overline{M B C}$ & MIC & $\mathrm{MBC}$ \\
\hline & $(\% \vee / v)$ & $(\% \mathrm{v} / \mathrm{v})$ & $(\% \vee / v)$ & $(\% \vee / v)$ & $(\% \mathrm{v} / \mathrm{v})$ & $(\% \mathrm{v} / \mathrm{v})$ \\
\hline PA01 & 0.1125 & 0.225 & 1.8 & $>1.8$ & 1.8 & $>1.8$ \\
\hline PA04 & 0.1125 & 0.225 & 1.8 & $>1.8$ & 1.8 & $>1.8$ \\
\hline PA05 & 0.1125 & 0.225 & $>1.8$ & $>1.8$ & 0.9 & 0.9 \\
\hline PA07 & 0.225 & 1.8 & 1.8 & 1.8 & 1.8 & 1.8 \\
\hline PA12 & 0.1125 & 0.225 & $>1.8$ & $>1.8$ & 1.8 & 1.8 \\
\hline PA13 & 0.225 & 0.225 & 1.8 & $>1.8$ & 1.8 & 1.8 \\
\hline PA16 & 0.1125 & 0.225 & 1.8 & $>1.8$ & 0.9 & 1.8 \\
\hline PA17 & 0.225 & 0.225 & $>1.8$ & $>1.8$ & 1.8 & $>1.8$ \\
\hline PA18 & 0.1125 & 0.225 & 1.8 & $>1.8$ & 0.9 & $>1.8$ \\
\hline PA19 & 0.1125 & 0.225 & 1.8 & $>1.8$ & 1.8 & $>1.8$ \\
\hline PA25 & 0.1125 & 0.1125 & 0.9 & $>1.8$ & 0.45 & 1.8 \\
\hline PA26 & 0.1125 & 0.225 & $>1.8$ & $>1.8$ & 1.8 & $>1.8$ \\
\hline PA31 & 0.1125 & 0.1125 & 1.8 & $>1.8$ & 1.8 & $>1.8$ \\
\hline PA34 & 0.1125 & 0.225 & 1.8 & $>1.8$ & 0.9 & $>1.8$ \\
\hline PA35 & 0.225 & 0.225 & 1.8 & $>1.8$ & 1.8 & $>1.8$ \\
\hline PA36 & 0.225 & 0.225 & 1.8 & $>1.8$ & 1.8 & $>1.8$ \\
\hline PA38 & 0.1125 & 0.225 & 1.8 & $>1.8$ & 0.9 & $>1.8$ \\
\hline PA41 & 0.0562 & 0.225 & 1.8 & $>1.8$ & 1.8 & $>1.8$ \\
\hline PA43 & 0.1125 & 0.225 & 1.8 & $>1.8$ & 0.9 & 1.8 \\
\hline PA45 & 0.1125 & 0.1125 & 1.8 & $>1.8$ & 1.8 & $>1.8$ \\
\hline
\end{tabular}

the total of 21 plant oils [22]. Warnke et al. [23] conducted a study including the activities of various essential oils using disc diffusion against MDR strains of Staphylococcus spp., Streptrococcus spp. and Candida spp. It revealed that thyme, lemon, lemongrass, cinnamon, tea tree, eucalyptus, grapefruit, clove bud, kunzea, sandalwood, peppermint, sage, and lavender oils affected on all tested microorganisms while olive and paraffin oil showed no activity. Essential oils from Thai medicinal plants including Zingiber cassumuna, Cinnamomum bejolghota, Mentha arvensis var. piperacens, Cymbopogon citrates, and Ocimum basilicum var. citratum demonstrated antibacterial activity against zoonotic enteropathogens including Salmonella spp., E. coli O157, Campylobacter jejuni, and Clostridium perfringens [24].

\section{Determination of the active compounds of cinnamon bark oil}

The bioautographic assay was performed to determine the major active compounds of cinnamon bark oil. The results showed that cinnamon bark oil contained at least 8 compounds with the major active constituent having $R_{f}$ of 0.6125 closely to the $R_{f}$ of the cinnamaldehyde standard. Another component found in cinnamon bark oil was eugenol with $R_{f}$ of 0.5625 . The inhibition zones of cinnamon bark oil, eugenol and cinnamaldehyde against the growth of $P$. aeruginosa PAO1 and MDR-PA isolates were clearly shown. The clear zones locating separately on TLC suggested that cinnamon bark oil showed antibacterial activity similar to cinnamaldehyde while eugenol showed lower antibacterial activity than cinnamon bark oil (Fig. 1).

Cinnamaldehyde is considered to be an aromatic aldehyde substance found approximately $60-70 \%$ in cinnamon bark oil [25]. The results of TLC and bioautographic assay in this study showed that the major compounds in cinnamon bark oil were mainly composed of cinnamaldehyde and eugenol. Cinnamaldehyde possessed better activity than eugenol against $P$. aeruginosa.

\section{Antibacterial activity of cinnamon bark oil and cinnamaldehyde under gaseous condition}

Due to the nature of essential oils being odorous and volatile, antibacterial activities of the selected essential
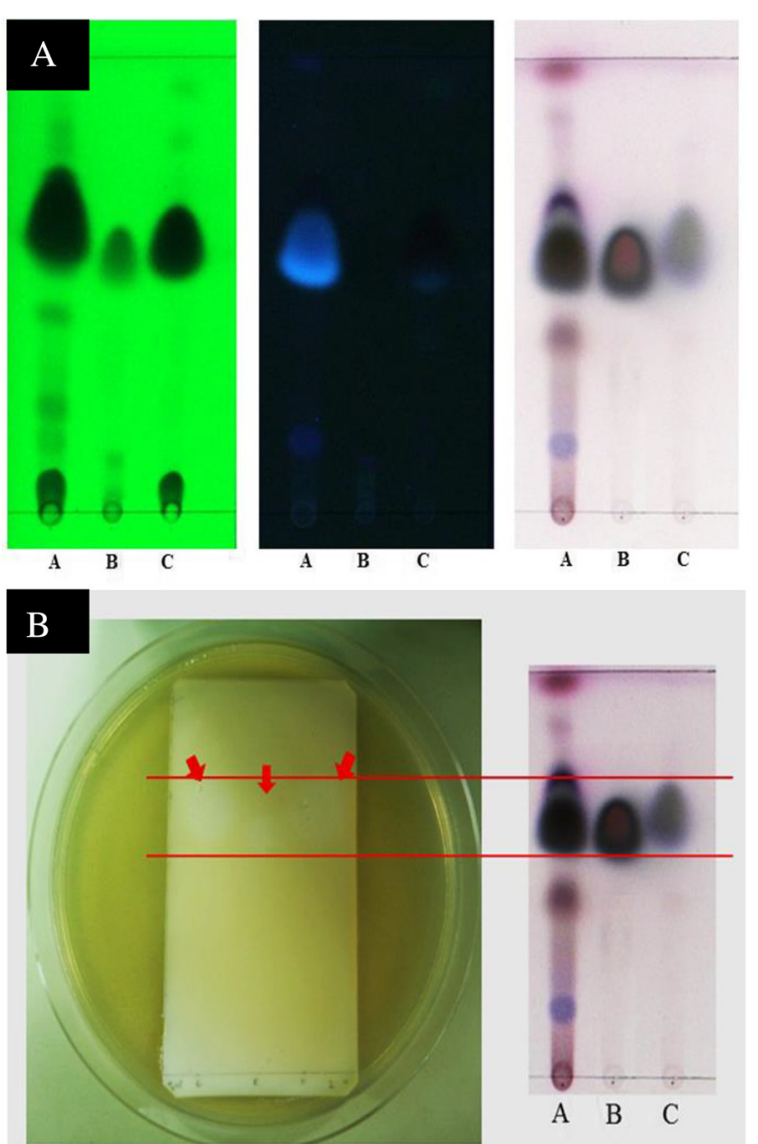

Fig. 1 TLC chromatogram of cinnamon bark oil. TLC fingerprints of essential oils were developed by toluene and ethyl acetate with ratio of 93:7 V/V and visualized under UV light $254 \mathrm{~nm}$ (left), $366 \mathrm{~nm}$ (center) and visible light (right) (a). Bioautographic assay against $P$. aeruginosa was demonstrated (b). Lane A, cinnamon bark oil; lane B, eugenol; lane C, cinnamaldehyde. Arrows indicate inhibition zone by active compounds 
oils were also determined under vapor phase condition. Cinnamon bark oil and cinnamaldehyde demonstrated promising activity of gas phase against $P$. aeruginosa PAO1 and MDR-PA isolates with MID in a range of 0.5 to $1 \mathrm{mg} / \mathrm{L}$ air while eugenol, lemongrass and clove oil showed less inhibition activity with MID more than $1 \mathrm{mg} / \mathrm{L}$ air.

Under vapor condition, cinnamon bark oil and cinnamaldehyde also showed strong activity on MDR-PA. Some studies on vapor-phase antimicrobial activity of six essential oils on foodborne pathogens demonstrated that clove and cinnamon oil possessed more antibacterial activity than rosemary, basil, ginger, and dill oil against Gram-positive bacteria, Gram-negative bacteria, and three fungi in disc diffusion method [26]. Moreover, there was a study of antimicrobial effect of cinnamaldehyde on air-borne microbes. The study exhibited that cinnamaldehyde reduced germ count to $45 \%$ after sprayed in the room [27].

\section{Time-killing effects of cinnamon bark oil and cinnamaldehyde}

$P$. aeruginosa PAO1 was challenged with cinnamon bark oil or cinnamaldehyde at various concentrations and bacterial viability was determined at different time points during incubation. The results showed that bacterial cells were killed within 1.3 and $2 \mathrm{~h}$ after treated with $1 \mathrm{xMIC}$ of cinnamaldehyde and cinnamon bark oil, respectively. Time-killing graphs demonstrated the reduction of viable cell approximately $6 \log \mathrm{CFU} / \mathrm{ml}$ after $P$. aeruginosa PAO1 and MDR-PA contacted with the compound for 2 and $4 \mathrm{~h}$, respectively (Fig. 2). Moreover, the higher concentrations of cinnamon oil and cinnamaldehyde (4xMIC) could efficiently eradicate MDR-PA within $1 \mathrm{~h}$. These results suggested that cinnamon bark oil and cinnamaldehyde acted in dose-dependent manner on $P$. aeruginosa. Our study also reported that of cinnamon oil and its major compound at the studied concentrations showed significant effect on bacterial growth indicating dosedependent inhibition activity in agreement with the group of Mayaud et al. [25].

\section{Synergistic effect of cinnamon bark oil/cinnamaldehyde and currently used antibiotics}

P. aeruginosa $\mathrm{PAO} 1$ and 30 clinical isolates of MDR-PA were determined antimicrobial susceptibility with 7 antibiotics for MIC, $\mathrm{MIC}_{50}$ and $\mathrm{MIC}_{90}$ (Table 2). The results showed that COL had minimal MIC interval at 2-8 $\mu \mathrm{g} /$ $\mathrm{ml}$. $\mathrm{MIC}_{50}$ and $\mathrm{MIC}_{90}$ of COL was 4 and $8 \mu \mathrm{g} / \mathrm{ml}$, respectively. CAZ showed maximum MIC interval at 2 to more than 2,048 $\mu \mathrm{g} / \mathrm{ml}$. Interestingly, most MDR-PA isolates were resistant to MEM, CIP, and CAZ.
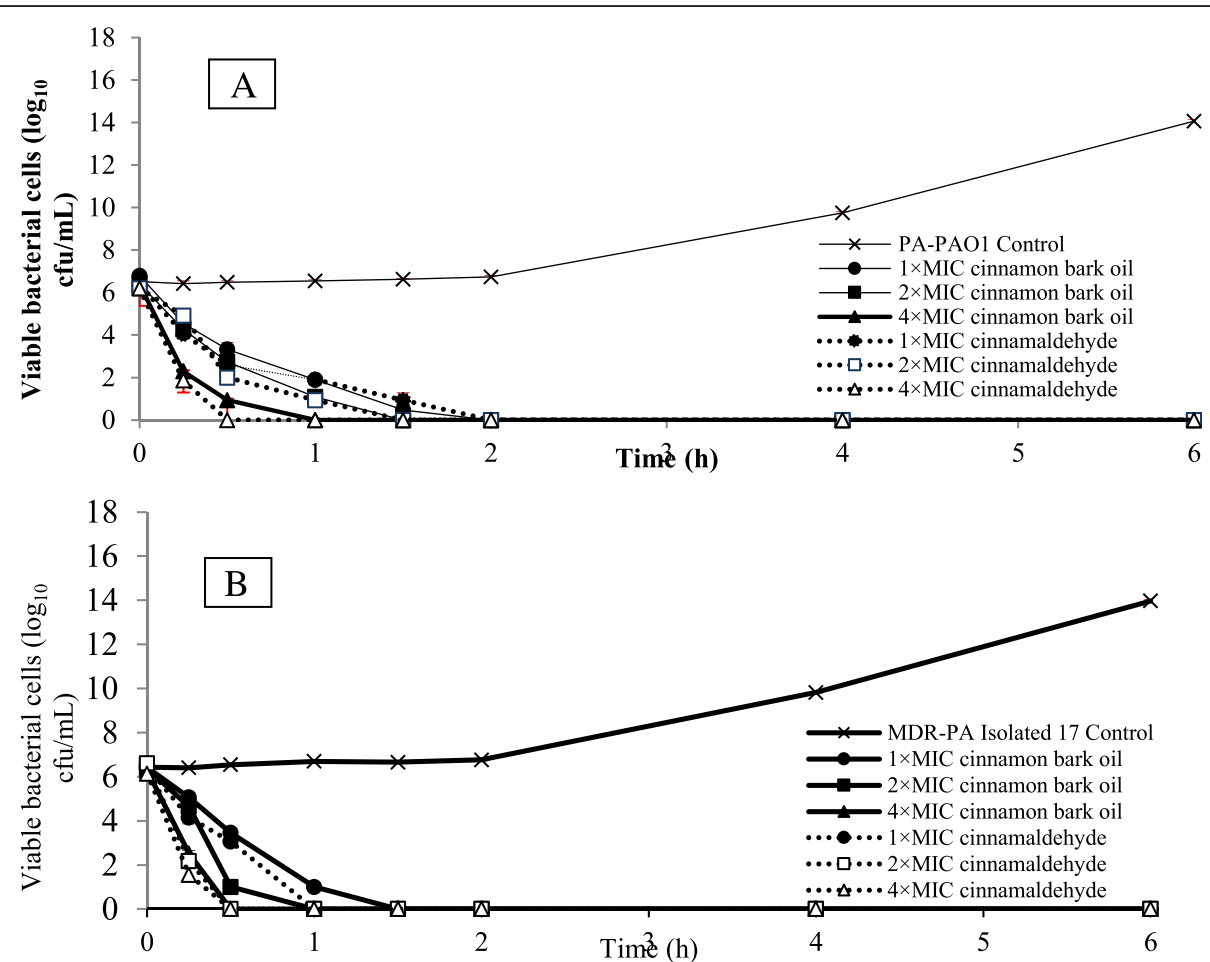

Fig. 2 Time killing assay of cinnamon bark oil and cinnamaldehyde. P. aeruginosa PAO1 (a) and MDR-PA (b) were collected to observe viable cells after exposure to essential oils and incubated at $37^{\circ} \mathrm{C}, 150 \mathrm{rpm}$. The results are expressed as mean values \pm standard deviation of three independent experiments 
Table 2 Antimicrobial susceptibility of 30 clinically isolated MDR-PA strains against currently used antibiotics

\begin{tabular}{lllllll}
\hline Antibiotics & MIC range & MIC50 & MIC90 & \multicolumn{3}{c}{ \% susceptibility } \\
\cline { 7 - 9 } & $(\mu \mathrm{g} / \mathrm{ml})$ & $(\mu \mathrm{g} / \mathrm{ml})$ & $(\mu \mathrm{g} / \mathrm{ml})$ & $\mathrm{S}$ & $\mathrm{I}$ & $\mathrm{R}$ \\
\hline Colistin & $2-8$ & 4 & 8 & 23.3 & 63.4 & 13.3 \\
Meropenem & $1-1024$ & 16 & 64 & 3.3 & 6.7 & 90 \\
Imipenem & $2-512$ & 16 & 32 & $\mathrm{ND}$ & 16.7 & 83.3 \\
Doripenem & $0.5-256$ & $4-8$ & 16 & 3.3 & 43.3 & 53.4 \\
Ciprofloxacin & $0.5-128$ & 64 & 128 & 10 & $\mathrm{ND}$ & 90 \\
Piperacilin & $2-1024$ & 256 & 1024 & 36.7 & $\mathrm{ND}$ & 63.3 \\
Ceftazidime & $2->2048$ & $>2048$ & $>2048$ & 6.7 & 3.3 & 90 \\
\hline
\end{tabular}

MIC range MIC values from lowest to highest, MIC50 MIC is position of percentile 50, MIC90 MIC is position of percentile $90, S$ sensitive, COL $(\leq 2 \mu \mathrm{g} / \mathrm{ml})$, MEM $(\leq 2 \mu \mathrm{g} / \mathrm{ml})$, IMl $(\leq 2 \mu \mathrm{g} / \mathrm{ml})$, DOR $(\leq 2 \mu \mathrm{g} / \mathrm{ml}), \mathrm{CIP}(\leq 1 \mu \mathrm{g} / \mathrm{ml}), \mathrm{PIP}(\leq 16 \mu \mathrm{g} / \mathrm{ml})$, and CAZ $(\leq 8 \mu \mathrm{g} / \mathrm{ml})$, I intermediate, COL $(4 \mu \mathrm{g} / \mathrm{ml})$, MEM $(4 \mu \mathrm{g} / \mathrm{ml})$, IMI $(4 \mu \mathrm{g} / \mathrm{ml})$, DOR $(4 \mu \mathrm{g} / \mathrm{ml})$, CIP $(2 \mu \mathrm{g} / \mathrm{ml})$, PIP

Furthermore, synergistic interactions of ceftazidime, piperacillin, ciprofloxacin, meropenem, imipenem, doripenem, colistin and cinnamon bark oil or its major compound were further studied as a percentage of each couple combinations. Thirty MDR-PA isolates were tested in combination between antibiotics and cinnamon bark oil or its major active compound. Most of the combinations exhibited indifferent interaction of two active substances to bacterial isolates with FICI range of 0.5-4. Synergistic rates could be detected in some isolates which were at about $16.7 \%$ in COL combined with cinnamon bark oil, $10 \%$ in COL combined with cinnamaldehyde, and $3.3 \%$ in MEM combined with cinnamon bark oil. It was noteworthy that the antagonistic activities were not be detected in any combinations (Table 3 ).

Cinnamon bark oil and cinnamaldehyde possessed higher antibacterial activity of colistin and meropenem against MDR-PA strains. Cinnamon bark oil was suggested to act on bacterial membrane by dissipated potassium cation $\left(\mathrm{K}^{+}\right)$gradient leading to membrane damage and breakdown of permeability barrier resulting in cell death [28]. Domadia et al. described the mechanism of cinnamaldehyde which of bioactive compound was assembled into Z-ring at the site of cell separation by binding to FtsZ protein [29]. This data was an evidence to show a reduction of bacterial cell loading. Accumulation of various substances in cytoplasm and destruction of cytoplasmic membrane of bacteria could cause cellular substance leakage and cell death [30]. This might result in positive interaction in combination. Combination therapy is used for expanding the antimicrobial spectrum, reducing toxicity and decreasing the antimicrobial resistance during treatment. Moreover, the results in this work showed no regrowth of $P$. aeruginosa after exposed to cinnamon bark oil and trans-cinnamaldehyde over $24 \mathrm{~h}$.
Table 3 Interaction between antibiotics and cinnamon bark oil or cinnamaldehyde against 30 clinically isolated MDR-PA strains

\begin{tabular}{|c|c|c|c|c|}
\hline \multirow[t]{2}{*}{ Combinations } & & \multicolumn{3}{|c|}{$\begin{array}{l}\% \text { isolates of bacteria in each } \\
\text { interaction activity }\end{array}$} \\
\hline & & SYN & IND & ANT \\
\hline \multirow[t]{2}{*}{ Colistin } & Cinnamon bark oil & 16.7 & 83.3 & ND \\
\hline & Cinnamaldehyde & 10 & 90 & ND \\
\hline \multirow[t]{2}{*}{ Meropenem } & Cinnamon bark oil & 3.3 & 96.7 & ND \\
\hline & Cinnamaldehyde & ND & 100 & ND \\
\hline \multirow[t]{2}{*}{ Imipenem } & Cinnamon bark oil & ND & 100 & ND \\
\hline & Cinnamaldehyde & ND & 100 & ND \\
\hline \multirow[t]{2}{*}{ Doripenem } & Cinnamon bark oil & ND & 100 & ND \\
\hline & Cinnamaldehyde & ND & 100 & ND \\
\hline \multirow[t]{2}{*}{ Ciprofloxacin } & Cinnamon bark oil & ND & 100 & ND \\
\hline & Cinnamaldehyde & ND & 100 & ND \\
\hline \multirow[t]{2}{*}{ Piperacillin } & Cinnamon bark oil & ND & 100 & ND \\
\hline & Cinnamaldehyde & ND & 100 & ND \\
\hline \multirow[t]{2}{*}{ Ceftazidime } & Cinnamon bark oil & ND & 100 & ND \\
\hline & Cinnamaldehyde & ND & 100 & ND \\
\hline
\end{tabular}

SYN synergy, IND indifferent, $A N T$ antagonist, $N D$ not detected

\section{Conclusions}

Cinnamon bark oil is an essential oil obtained from the bark of Cinnamomum zeylanicum which belongs to Lauraceae family and usually grows in South and Southeast Asia. The current study reported that cinnamon bark oil and cinnamaldehyde possessed high bactericidal activity against MDR-PA isolates. Moreover, it showed promising tendency of combination with colistin, the currently used drug for treatment of gram-negative bacterial infection. Therefore, this could be a compound used for beneficial human health, considering as an alternative therapeutic agent for medical application and anti-bacterial supplement in health products, especially natural active compounds that might reduce the cost and could be safe. However, the further studies including the in vivo toxicity studies and clinical trials on cinnamon oil or its active compound to determine pharmacodynamics and pharmacokinetics are still necessary.

\footnotetext{
Abbreviations

CAZ, ceftazidime; CIP, ciprofloxacin; COL, colistin sulfate; DOR, doripenem; $\mathrm{FICl}$, fractional inhibitory concentration index; IMI, imipenem; MBCs, minimum bactericidal concentrations; MDR-PA, multidrug resistant $P$. aeruginosa; MEM, meropenem; MICs, minimum inhibitory concentrations; MID, minimum inhibitory dose; PIP, piperacillin; TLC, thin-layer chromatography.
}

\section{Acknowledgement}

The authors acknowledge the Thailand Graduate Institute of Science and Technology (TGIST 01-55-045) by National Science and Technology Development Agency (NSTDA) for the financial grant. We would like to extend our thanks to the Thailand Research Fund and Faculty of Pharmacy, Mahidol University (IRG5780007) for financial support on publication. The authors wish to thank all staffs in the Department of Microbiology for help and suggestion on this work. 


\section{Funding}

The authors acknowledge the Thailand Graduate Institute of Science and Technology (TGIST 01-55-045) by National Science and Technology Development Agency (NSTDA) for the financial grant of this work.

\section{Availability of data and materials}

The dataset supporting the conclusions of this article is included within the article.

\section{Authors' contributions}

MTC was responsible for study design, experimental guidance and drafted the manuscript. Experimental work was performed by IU. SS gave technical comments and participated in some experiments. PK provided information on multidrug-resistant strains and laboratory techniques. MJ provided cinnamaldehyde and gave some technical comments. All authors reviewed and approved the final version.

\section{Competing interests}

The authors declare that they have no competing interests.

\section{Consent for publication}

Not applicable.

\section{Ethics approval and consent to participate}

Not applicable.

\section{Author details}

${ }^{1}$ Department of Microbiology, Faculty of Pharmacy, Mahidol University, 447 Sri Ayudthaya Road, Rachathevi, Bangkok 10400, Thailand. ${ }^{2}$ National Nanotechnology Center (NANOTEC), National Science and Technology Development Agency, Khlong Luang, Thailand. ${ }^{3}$ Department of Manufacturing Pharmacy, Faculty of Pharmacy, Mahidol University, Bangkok, Thailand.

\section{Received: 30 November 2015 Accepted: 18 May 2016}

Published online: 01 June 2016

\section{References}

1. Rossolini GM, Mantengoli E. Treatment and control of severe infections caused by multiresistant Pseudomonas aeruginosa. Clin Microbiol Infect. 2005;11 Suppl 4:17-32

2. Lambert PA. Mechanisms of antibiotic resistance in Pseudomonas aeruginosa. J R Soc Med. 2002;95 Suppl 41:22-6.

3. Narten M, Rosin N, Schobert M, Tielen P. Susceptibility of Pseudomonas aeruginosa urinary tract isolates and influence of urinary tract conditions on antibiotic tolerance. Curr Microbiol. 2012;64:7-16.

4. Borriello G, Werner E, Roe F, Kim AM, Ehrlich GD, Stewart PS. Oxygen limitation contributes to antibiotic tolerance of Pseudomonas aeruginosa in biofilms. Antimicrob Agents Chemother. 2004;48:2659-64.

5. Giannakopoulos X, Evangelou A, Kalfakakou V, Grammeniatis E, Papandropoulos I, Charalambopoulos K. Human bladder urine oxygen content: implications for urinary tract diseases. Inter Urol Nephrol. 1997:29:393-401.

6. Jones FA. Herbs-useful plants. Their role in history and today. Eur J Gastroenterol Hepatol. 1996;8:1227-31.

7. Aridogan BC, Baydar H, Kaya S, Demirci M, Ozbasar D, Mumcu E. Antimicrobial activity and chemical composition of some essential oils. Arch Pharmacol Res. 2002;25:860-4.

8. Delaquis PJ, Stanich K, Girard B, Mazza G. Antimicrobial activity of individual and mixed fractions of dill, cilantro, coriander and eucalyptus essential oils. Int J Food Microbiol. 2002;74:101-9.

9. Magiatis P, Skaltsounis AL, Chinou I, Haroutounian SA. Chemical composition and in vitro antimicrobial activity of the essential oils of three Greek Achillea species. Z Naturforsch C. 2002;57:287-90.

10. Chamdit S, Siripermpool P. Antimicrobial effect of clove and lemongrass oils against planktonic cells and biofilms of Staphylococcus aureus. Mahidol Univ J Pharm Sci. 2012;39(2):28-36.

11. Loy G, Cottiglia F, Garau D, Deidda D, Pompei R, Bonsignore L. Chemical composition and cytotoxic and antimicrobial activity of Calycotome villosa (Poiret) link leaves. Farmaco. 2001;56:433-6.

12. Shafi PM, Rosamma MK, Jamil K, Reddy PS. Antibacterial activity of the essential oil from Aristolochia indica. Fitoterapia. 2002;73:439-41.
13. Si H, Hu J, Liu Z, Zeng ZL. Antibacterial effect of oregano essential oil alone and in combination with antibiotics against extended-spectrum betalactamase-producing Escherichia coli. FEMS Immunol Med Microbiol. 2008:53:190-4.

14. Pereira RS, Sumita TC, Furlan MR, Jorge AO, Ueno M. Antibacterial activity of essential oils on microorganisms isolated from urinary tract infection. Rev Saude Publica. 2004;38:326-8.

15. Khuntayaporn P, Montakantikul P, Mootsikapun P, Thamlikitkul V, Chomnawang MT. Prevalence and genotypic relatedness of carbapenem resistance among multidrug-resistant P. aeruginosa in tertiary hospitals across Thailand. Ann Clin Microbiol Antimicrob. 2012;11:25.

16. Rodrigues FF, Costa JG, Coutinho HD. Synergy effects of the antibiotics gentamicin and the essential oil of Croton zehntneri. Phytomedicine. 2009;16:1052-5.

17. CLSI. Performance standards for antimicrobial susceptibility testing; Twentysecond information supplement. CLSI document M100-S22. Wayne: Clinical and Laboratory Standard Institute; 2012.

18. Garcia L. Synergism testing: broth microdilution checkerboard and broth macrodilution methods. In: Garcia L, editor. Clinical microbiology procedure handbook. 3rd ed. Washinton, DC: American Society for Microbiology; 2010. p. 512-23.

19. Shahverdi AR, Monsef-Esfahani HR, Tavasoli F, Zaheri A, Mirjani R. Cinnamaldehyde from Cinnamomum zeylanicum bark essential oil reduces the clindamycin resistance of Clostridium difficile in vitro. J Food Sci. 2007;72:S055-8.

20. Chomnawang MT, Surassmo S, Wongsariya K, Bunyapraphatsara N. Antibacterial activity of Thai medicinal plants against methicillin-resistant Staphylococcus aureus. Fitoterapia. 2009:80:102-4.

21. Nuryastuti T, van der Mei HC, Busscher HJ, Iravati S, Aman AT, Krom BP. Effect of cinnamon oil on icaA expression and biofilm formation by Staphylococcus epidermidis. Appl Environ Microbiol. 2009;75:6850-5.

22. Prabuseenivasan S, Jayakumar M, Ignacimuthu S. In vitro antibacterial activity of some plant essential oils. BMC Complement Altern Med. 2006:6:39.

23. Warnke PH, Becker ST, Podschun R, Sivananthan S, Springer IN, Russo PA, Wiltfang J, Fickenscher $\mathrm{H}$, Sherry $\mathrm{E}$. The battle against multi-resistant strains: Renaissance of antimicrobial essential oils as a promising force to fight hospital-acquired infections. J Cranio Maxillo Fac Surg. 2009:37:392-7.

24. Wannissorn B, Jarikasem S, Siriwangchai T, Thubthimthed S. Antibacterial properties of essential oils from Thai medicinal plants. Fitoterapia. 2005;76:233-6.

25. Mayaud L, Carricajo A, Zhiri A, Aubert G. Comparison of bacteriostatic and bactericidal activity of 13 essential oils against strains with varying sensitivity to antibiotics. Lett Appl Microbiol. 2008;47:167-73.

26. Lopez P, Sanchez C, Batlle R, Nerin C. Vapor-phase activities of cinnamon, thyme, and oregano essential oils and key constituents against foodborne microorganisms. J Agric Food Chem. 2007;55:4348-56.

27. Sato K, Krist S, Buchbauer G. Antimicrobial effect of trans-cinnamaldehyde, (-)-perillaldehyde, (-)-citronellal, citral, eugenol and carvacrol on airborne microbes using an airwasher. Biol Pharm Bull. 2006;29:2292-4.

28. Bouhdid S, Abrini J, Amensour M, Zhiri A, Espuny MJ, Manresa A. Functional and ultrastructural changes in Pseudomonas aeruginosa and Staphylococcus aureus cells induced by Cinnamomum verum essential oil. J Appl Microbiol. 2010;109:1139-49.

29. Domadia P, Swarup S, Bhunia A, Sivaraman J, Dasgupta D. Inhibition of bacterial cell division protein FtsZ by cinnamaldehyde. Biochem Pharmacol. 2007;74:831-40.

30. Bakkali F, Averbeck S, Averbeck D, Idaomar M. Biological effects of essential oils-a review. Food Chem Toxicol. 2008;46:446-75. 